\title{
Effect of combination among bioagents, compost and soil solarization on management of strawberry Fusarium wilt
}

\author{
Abada K. A. ${ }^{1}$, Faten M. Abd-El-Latif ${ }^{2}$, Hala A.M. El-Dakar ${ }^{3}$ \\ ${ }^{1}$ Plant Pathol. Dept., Fac. Agric., Cairo Univ., Giza, Egypt \\ ${ }^{2}$ Agric. Botany Dept., Fac. Agric., Benha Univ.,Moshtohor, Egypt \\ ${ }^{3}$ Integ. Cont. Res. Dept., Plant Pathol.Res. Instit., Agric. Res. Centre, Giza, Egypt \\ Email address: \\ dr_khairy_abada@yahoo.com (Abada K. A.)
}

\section{To cite this article:}

Abada K. A., Faten M. Abd-El-Latif, Hala A.M. El-Dakar. Effect of Combination among Bioagents, Compost and Soil Solarization on Management of Strawberry Fusarium Wilt. American Journal of Life Sciences. Special Issue: Role of Combination Between Bioagents and Solarization on Management of Crown-and Stem-Rot of Egyptian Clover. Vol. 2, No. 6-2, 2014, pp. 39-46.

doi: 10.11648/j.ajls.s.2014020602.16

\begin{abstract}
Isolation trials from strawberry plants showing mainly wilt symptoms grown at Behera, Ismailia, Kalubia and Giza governorates yielded Fusarium oxysporum, F.solani, Macrophomina phaseolina, Pythium ultimum , Phytophthora cactorum, Rhizoctonia solani and Sclerotium rolfsii . Pathogenicity test of the four isolates of F.oxysporum revealed that they caused wilt symptoms and Kalubia isolate was the most virulent one. In addition, inoculating different seven plants, i.e. bean, cucumber, eggplant, sweet pepper, strawberry, tomato and water melon with F. oxysporum isolate of Kalubia governorate indicated that it caused wilt symptoms to strawberry plants only. Therefore, it named Fusarium oxysporum f.sp. fragariae Winks \& Y.N. Williams. Four isolates of Bacillus spp., i.e. Bacillus coagulans, B.humilus, B.subtils and B. thringiensis and one isolate of Pseudomonas flurescens were isolated from the rhizospheric soil of strawberry plants grown in a field have severe infection by Fusarium wilt were screened for their efficacy against $F$. $o$. f.sp. fragariae, in vitro and in vivo. In general, P.flurescens followed by Bacillus subtilis were the most efficient in reducing the linear growth of the pathogenic fungus. Sterilized aqueous filtrate of the tested compost resulted in significant reduction to the linear growth of the tested fungus compared with control treatment. This reduction was gradually increased by increasing it's concentration. The combination among the bioagents B.subtilis and P.flurescens, compost and soil solarization resulted in significant reduction to strawberry Fusarium wilt with significant increase to the produced fruits and their total soluble solids (T.S.S.), either each of them was used alone or in their different combinations, compared with control treatment (infested with the causal fungus). On the other hand, compost was the most efficient in this regard compared with the other three items of disease management, i.e. soil solarization and the bioagents B.subtilis and P.flurescens when each of them was used alone. Moreover, no apparent infection was detected when the bioagents B.subtilis and P.flurescens, compost and soil solarization were used together and produced fruit yield of T.S.S., to somewhat, similar to control treatment ( uninfested soil with the causal fungus).
\end{abstract}

Keywords: Bacterial Bioagents, Compost, Fruit Yield, Management, Strawberry and Total Soluble Solids

\section{Introduction}

Strawberry (Fragaria $\times$ ananassa) is one of the most important and delicious untraditional crops in Egypt for local consumption and exportation. It is liable to infection by many soil borne fungi. However, Fusarium wilt poses a serious threat to commercial strawberry production worldwide and causes severe economic losses (Attia et al., 1989 ; Fang et al.,2011 and 2012 and Juber et al., 2014).

Strawberry is grown in most arable regions of the world.
The crop is enjoyed by millions of people in all kinds of climates including temperate, Mediterranean, subtropical and taiga zones.

During the last decade many complains have been received from strawberry growers due to the death of strawberry plants due to the infection by wilt beginning from beginning of March to end of the growing season.

Fusarium wilt of strawberry caused by $F$. oxysporum f. sp. 
fragariae is responsible for causing yield losses in commercial strawberry production (Fang et al., 2011 and 2012 and Juber et al., 2014). The causal agent is a haploid fungus and is difficult to control because the pathogen survives as chlamidospores in soil for many years. Early detection and diagnosis of the pathogen in plants and soils is essential for development of an effective disease control strategy. The control of Fusarium wilt disease is currently accomplished primarily through the use of soil fumigation by methyl bromide as well as fungicides and, to somewhat, resistant cvs. However the frequent and discriminate use of soil fumigation and fungicides leads to atmosphere pollution and create imbalance in the microbial community, which maybe unfavorable to the activity of beneficial organisms and may lead to development of resistance strains of the pathogen (Martin \& Bull, 2002). In recent years biological control has become a promising safer and ecologically acceptable alternative to chemical control in the management of soil borne diseases (Shalini and Srivastar, 2007 and Abada and Ahmed, 2014). Among the bacterial bioagents, genera Bacillus Pseudomonas received more attention than many other bacterial groups ( Santoyo et al., 2012).

Due to strawberry is consumed mainly as fresh or canned, therefore disease management rather than chemical control must be done. In this regard, biological control has emerged as an alternative and most promising means of the management of plant pathogens. Biocontrol of the causal of Fusarium wilt of strawberry can be achieved by either promoting the native antagonists such as that found in compost to reach a density sufficient to suppress pathogen(s) or by introducing alien antagonists. Among the several antagonists tested by various scientists, genera of Bacillus and Pseudomonas .... etc., have been found effective in inhibiting the causal of many soil borne pathogens ( Fang et al.,2012 ; Abada and Ahmed, 2014 and Juber et al., 2014 ). Though introduction of several antagonists against this pathogen seems to hold great promise to suppress the disease and have been found effective in inhibiting the growth of the tested fungus under in vitro conditions.

Also, Stapleton and Devay (1986) mentioned that soil solarization has been effective as a pre-plant and as a postplant treatment, and has been compatible with chemical soil treatments and also biological soil amendments after solarization. Soil solarization is a significant advance in the non-chemical control of many pathogens and pests.

The present investigation aimed to investigate the role of the bioagents in combination with compost and soil solarization in management of strawberry Fusarium wilt .

\section{Materials and Methods}

\subsection{Isolation, Purification and Identification of the Associated Fungi to Fusarium Wilt}

Strawberry plants showing characteristic wilt symptoms were collected from Behera, Ismailia, Kalubia and Giza governorates. The infected crown samples were thoroughly washed in running tap water and cut into small pieces with lesion having half healthy and half diseased tissue. The pieces were surface sterilized with $2 \%$ sodium hypochlorite for two minutes. The tissue pieces were subsequently washed in three changes of sterile distilled water to eliminate excess sodium chlorite and then the pieces were transferred onto PDA medium in Petri dishes. Plates were incubated at $20 \pm$ $2{ }^{\circ} \mathrm{C}$ and observed periodically for growth of the fungi. Axenic culture of the isolated fungi was obtained by single spore technique or hyphal tip method and maintained on PDA slants throughout the investigation. The emerged fungi were identified on the basis of cultural, morphological characteristics and the description of Booth (1971) and Domsch et al. (1980).

\subsection{Isolation, Purification and Identification of the Bacterial Antagonists}

Soil samples collected from the rhizospheric soil of strawberry plants grown in a field have severe infection by Fusarium strawberry wilt, were used to isolate the antagonists. Serial dilution plate technique (Johnson and Curl, 1959) was used to isolate native antagonistic Bacillus spp. and Pseudomonas flurescens on nutrient agar medium (Oedjijono and Dragar,1993).The isolated bacteria were then purified and identified depending on the description of Parry et al. (1983) and Holt and Krieg (1984). The identification was confirmed by the Biolog System technique (Biological control of faba bean chocolate spot disease project, Plant Pathol. Res. Instit., A.R.C., Giza, Egypt).

\subsection{Pathogenicity Test}

Formalin disinfested clay soil was infested by $2 \%$ inoculum level of the four isolates of F.oxysporum, each alone and distributed in Plastic post $(25 \mathrm{~cm}$ in diameter). Camarosa strawberry cv. transplants were dipped in $1 \%$ of the fungicide Rizolex-T (Tolcolfos- methyl) for 30 minutes to make sour that the transplants were uninfected with any fungal pathogen then 2 transplants were transplanted in each pot. Transplanted transplants in uninfested soil were used as control. The severity of Fusarium wilt was assessed four months after transplanting. Plant growth vigor $(+=$ poor growth,$++=$ good growth and $+++=$ excellent growth) was also noticed and recorded.

In addition, bean ( Pronco cv.), cucumber ( Amera cv.), eggplant( Balady white cv.), sweet pepper ( Balady cv.), strawberry( Camarosa cv.), tomato (GS cv.) and water melon (Giza $1 \mathrm{cv}$.) plants were grown in plastic pots infested or not with $F$. oxysporum isolate of Kalubia governorate and left two grow for two months, then incidence of Fusarium wilt was recorded.

\subsection{Effect of the Culture Filtrate of the Bioagents on the Linear Growth of the Tested Pathogen}

The effect of the culture filtrate of the four isolates of Bacillus spp. and Pseudomonas flurescens on the growth of F.o. f.sp. fragariae was studied as a method given by Dennis 
and Webster (1971).

One hundred ml. of nutrient medium were put in each 250 $\mathrm{ml}$ flask and sterilized by steamer for three successive days. The medium was inoculated with a loop of the bioagent(s) taken from two days-old culture. Inoculated flasks were incubated on a rotary shaker at $200 \mathrm{rpm}$ for 3 days at $30 \pm$ $2{ }^{\circ} \mathrm{C}$. The culture filtrate was filtered through Whatman No. 1 filter paper and the filtrate was collected in a flask. The culture filtrate of the bioagents was mixed with the component of PDA medium in different proportion $(25,50$, 75 and $100 \%$ ). The medium was then sterilized by steamer for three successive days and poured into Petri-dishes (20 $\mathrm{ml} /$ plate).

After solidification the Petri-dishes were carefully inoculated with $5 \mathrm{~mm}$. discs of the test pathogen cut from the five day old culture. PDA plates inoculated with the test pathogen, but not amended with culture filtrate of the bioagents were maintained as control. Plates were then incubated in an incubator at $30 \pm 2^{\circ} \mathrm{C}$. Five replicates were maintained for each treatment. Periodic observations on the linear growth of the tested fungus were recorded. Inhibition percentage of the mycelial growth of test pathogens was calculated by the formula:

$\mathrm{I}=(\mathrm{C}-\mathrm{T}) / \mathrm{C}$ X100

Where; $\mathrm{I}=$ Percent of inhibition in growth of test pathogen , $\mathrm{C}=$ Radial growth of pathogen $(\mathrm{mm})$ in control , $\mathrm{T}=$ Radial growth of pathogen $(\mathrm{mm})$ in treatment.

\subsection{Effect of Filtrate of Soaked Compost on the Linear Growth of the Causal Pathogen}

One $\mathrm{kg}$ compost was soaked overnight in one liter water then filtrate through two layers of Whatman 1 filter paper. The counted amounts of potato broth, dextrose and agar were added to $20,40,60,80$ and $100 \%$ of the filtrate and steamed for three successive days then poured in sterilized Petridishes. After solidification the Petri-dishes were carefully inoculated with $5 \mathrm{~mm}$. discs of the test pathogen cut from the five day old culture. PDA plates inoculated with the test pathogen, but not amended with compost filtrate (normal PDA) were maintained as control. Plates were then incubated in an incubator at $30 \pm 2^{\circ} \mathrm{C}$. Five replications were maintained for each treatment. Periodic observations on the linear growth of the tested fungus were recorded (Khan 2007). Inhibition percentage of the mycelial growth of test pathogens was calculated as mentioned before.

\subsection{Effect of Combination among Compost, the Two Bioagents B.subtilis and P.flurescens and Soil Solarization on Management of Fusarium Wilt and Some Crop Parameters}

In the present investigation, transplants of Camarosa strawberry cv. taken from Strawberry Development Center, Fac. Agric., Ain Shams Univ. were used. The pathogen was isolated from strawberry crowns by tissue segment method on PDA medium. The highly antagonistic bioagents B.subtilis and P.flurescens against the test pathogen in vitro were used in management of strawberry Fusarium wilt in combination with compost and soil solarization.

The upper $20 \mathrm{~cm}$, layer of each plot $\left(1 \mathrm{~m}^{2}\right)$, located in the experimental unit of Plant Pathol. Dept., Fac., Cairo Univ., was infested with $2 \%$ inoculum level (grown on sterilized corn-sand medium in $500 \mathrm{ml}$. glass bottles) of the tested pathogen. The plots were divided into the following treatments:

1 Three infested plots with the causal pathogen received 2 $\mathrm{kg}$ compost for each plot (mixed thoroughly with the upper $20 \mathrm{~cm}$ soil layer).

2 Three infested plots with the causal pathogen were infested with the bioagent B.subtilis ( $1 \times 10^{6} \mathrm{cfu} / \mathrm{L}$ water) at the rate of one $2 \mathrm{~L} /$ plot.

3 Three infested plots with the causal pathogen were infested with the bioagent P.flurescens ( $1 \times 10^{6} \mathrm{cfu} / \mathrm{L}$ water) at the rate of one $2 \mathrm{~L} /$ plot

4 Three infested plots with the causal pathogen were solarized with proliferated plastic sheets ( $50 \mu$ thick) during end of August, 2013 for 45 days.

5 Three infested plots with the causal pathogen received 2 $\mathrm{kg}$ compost for each plot and infested with the bioagent B.subtilis ( $1 \times 10^{6} \mathrm{cfu} / \mathrm{L}$ water) at the rate of $2 \mathrm{~L} /$ plot.

6 Three infested plots with the causal pathogen received 2 $\mathrm{kg}$ compost for each plot and infested with the bioagent P.flurescens ( $1 \times 10^{6} \mathrm{cfu} / \mathrm{L}$ water) at the rate of $2 \mathrm{~L} /$ plot.

7 Three infested plots with the causal pathogen received 2 $\mathrm{kg}$ compost for each plot and solarized as mentioned before.

8 Three infested plots with the causal pathogen were infested with both bioagents $1 \times 10^{6} \mathrm{cfu} / \mathrm{L}$ water) at the rate of $2 \mathrm{~L} /$ plot from each bioagent.

9 Three infested plots with the causal pathogen were solarized as mentioned before and infested with the bioagent B.subtilis at the previous rate after solarization.

10 Three infested plots with the causal pathogen were solarized as mentioned before and infested with the bioagent P.flurescens at the previous rate after solarization.

11 Three infested plots with the causal pathogen received 2 $\mathrm{kg}$ compost for each plot, solarized as mentioned before and infested with both bioagents at the previous rate after solarization.

12 Three infested plots with the causal pathogen were left without another treatment.

The plots were then irrigated and left for three days and hoe then transplanted with Camarosa strawberry cv. Transplants (frigo transplants) dipped in $1 \%$ of the fungicide Rizolex-T for 30 minutes just before transplanting (beginning of October, 2013) to make sour that the transplants were uninfected with any fungal pathogen. Twelve transplants were transplanted in each plot.

The plots were irrigated when it was necessary and fertilized with the recommended doses as recommended by Min. of Agric. and Land reclamation.

Disease severity was assessed on four randomly plants in each plot, six months after transplanting and the average was recorded. Also, the produced mature fruits were harvested periodically and the average was recorded. Furthermore, 
T.S.S. of five randomly fruits were measured using hand fractometer each harvest and the averages were recorded.

\subsection{Disease Assessment}

The plants were rated for vascular and leaf discoloration using the devised scale (0-5) by Ulloa et al.(2006) after modification as follows:

Where:

$0=$ No discoloration on the leaves and vascular (healthy),

$1=$ Light discoloration evident on the leaves and as spotty areas in the cross-section of the crown,

$2=$ More continuous discoloration on the leaves and covering an area between one quarter and one half of the cross-section of the crown but light in color,

$3=$ Leaves and vascular of moderate discoloration (moderate in color) evident in a band encircling almost the entire crown cross-section,

$4=$ Most leaves yellowish and vascular discoloration darker in color than in 1 or 2 , and evident across most of the vascular tissue in a cross section of the crown, and

5 = Plants severely damaged, leaves seemed to be burned and vascular discoloration evident throughout cross-section of the crown.

Disease severity was assessed using the following formula

$$
\text { Disease severity } \%=\frac{\sum(\mathrm{nxv})}{5 \mathrm{~N}} \times 100
$$

Where:

$\mathrm{n}=$ Number of the inspected samples in each category.

$\mathrm{v}=$ Numerical values of each category.

$\mathrm{N}=$ Total number of the inspected samples.

$5=$ The highest grade scale.

\subsection{Statistical Analysis}

Data were statistically analyzed using the standard procedures for split design as mentioned by Snedecor and Cochran (1967). The averages were compared at 5\% level using least significant differences (L.S.D) according to Fisher (1948).

\section{Results}

\subsection{Isolation, Purification and Identification of the Associated Fungi}

Isolation trials from strawberry plants (Camarosa cv.) showing characteristic symptoms of wilt collected from Behera, Ismailia , Kalubia and Giza governorates yielded many fungal isolates. The isolated fungi were purified and identified as : Fusarium oxysporum, F.solani ,Pythium ultimum,Phytophthora cactorum, Rhizontonia solani and Sclerotium rolfsii.

The isolates of the fungus $F$. oxysporum were selected and tested for their pathogenicity to choose the most virulent isolate.

\subsection{Pathogenicity Test of the Four Isolates of F. oxysporum}

Pathogenicity test of the four isolates of $F$. oxysporum (Table 1) reveal that they were pathogenic to Camarosa strawberry cv. and showing typical wilt symptoms on the foliage growth and the vascular. Results also, indicate that the isolate of Kalubia governorate was the most virulent one than the other isolates ( $51.3 \%$ wilt severity ) and of poor plant growth vigor. Therefore, it was used in the following experiments. Also, testing of bean (Pronco cv.), cucumber ( Amera cv), eggplant ( Balady white cv.), sweet pepper ( Balady cv.), strawberry ( Camarosa cv.), tomato ( GS cv.) and water melon ( Giza $1 \mathrm{cv}$.) to their susceptibility to the infection by $F$. oxysporum reveal that the highest infection by the fungus $F$. oxysporum was occurred only to strawberry and no infection was found in case of the other plants. Therefore, the fungus $F$. oxysporum named as Fusarium oxysporum f.sp. fragariae Winks \& Y.N. Williams.

\subsection{In Vitro Effect of Four Bacillus spp. and P.flurescens on the Linear Growth of the Tested Pathogen}

Results shown in Table (2) indicate that all the tested isolates of Bacillus spp. as well as P.flurescens resulted in different inhibitory effect to the linear growth of the causal fungus, 5 days after incubation at $30 \pm 2^{\circ} \mathrm{C}$ compared with control treatment. This reduction was gradually increased by increasing the concentration. In addition, the causal fungus greatly affected by both P.flurescens and B.subtilis , being 32.2 and $33.6 \mathrm{~mm}$., respectively and failed to grow on the concentration of $100 \%$ of both bioagents. Meanwhile, isolates of B.coagulans and B.humilus were the lowest efficient in this regard, being 44.3 and $43.3 \mathrm{~mm}$., respectively .

Table 1. Pathogenicity test of the four isolates of $F$. oxysporum using transplants of strawberry plants (Camarosa cv.), greenhouse experiment.

\begin{tabular}{lll}
\hline Governorates & \% Disease severity & Plant growth vigor * \\
\hline Behera & 42.5 & ++ \\
Ismailia & 48.1 & + \\
Kalubia & 51.2 & + \\
Giza & 44.3 & ++ \\
Control & 0.0 & +++ \\
\hline
\end{tabular}

* Plant growth vigor; $+=$ poor growth,$++=$ good growth and $+++=$ excellent growth

Table 2. In vitro effect of four Bacillus spp. and P.flurescens culture filtrate on the linear growth of F.o.f.sp. fragariae, 5 days after incubation at $30 \pm 2{ }^{\circ} \mathrm{C}$.

\begin{tabular}{lccccc}
\hline \multirow{2}{*}{ Bioagents } & \multicolumn{6}{c}{ linear growth $(\mathbf{m m})$ at concentration of $(\mathbf{\%})$} \\
\cline { 2 - 6 } & $\mathbf{2 5}$ & $\mathbf{5 0}$ & $\mathbf{7 5}$ & $\mathbf{1 0 0}$ & Mean \\
\hline B.coagulans & 73.4 & 46.6 & 37.0 & 20.2 & 44.3 \\
B.humilus & 71.2 & 45.8 & 36.8 & 19.4 & 43.3 \\
B.subtilis & 66.0 & 41.4 & 27.0 & 0.0 & 33.6 \\
B.thuringiensis & 69.6 & 44.2 & 33.2 & 10.0 & 39.3 \\
P.flurescens & 64.8 & 39.0 & 25.0 & 0.0 & 32.2 \\
Control & 90.0 & 90.0 & 90.0 & 90.0 & 90.0 \\
Mean & 72.5 & 51.2 & 41.5 & 23.3 & --- \\
\hline
\end{tabular}

L.S.D. at $5 \%$ for: Bioagent $\mathrm{s}(\mathrm{B})=2.5$, Concentration $(\mathrm{C})=3.3$ and $\mathrm{B} \times \mathrm{C}=$ 3.8 . 


\subsection{Effect of Filtrate of Compost on the Linear Growth of the Causal Pathogen}

Table 3. Effect of filtrate of compost linear growth of F. o.f.sp. fragariae five days after incubation at $30 \pm{ }^{\circ} \mathrm{C}$.

\begin{tabular}{ll}
\hline Concentrations $(\%)$ & Average linear growth $(\mathbf{m m})$ \\
\hline 20 & 81.0 \\
40 & 65.8 \\
60 & 42.4 \\
80 & 21.2 \\
100 & 0.0 \\
Control & 90.0 \\
L.S.D. at 5\% & 2.7 \\
\hline
\end{tabular}

Data presented in Table (3) show that the filtrate of compost caused significant reduction to the linear growth of F. o.f.sp. fragariae, five days after incubation at $30 \pm^{\circ} \mathrm{C}$ compared with control treatment This reduction was gradually increased by increasing the concentration. In addition, the causal fungus failed to grow on the concentration of $100 \%$

\subsection{Effect of Combination among the Bioagents B.subtilis and P.flurescens, Compost and Soil Solarization on Management of Strawberry Fusarium Wilt and fruit yield and it's T.S.S.}

Table (4) shows that combination among the bioagents B.subtilis and P.flurescens, compost and soil solarization resulted in significant reduction to strawberry Fusarium wilt with significant increase to the produced fruits and their total soluble solids (T.S.S.), either each of them was used alone or in their different combinations, compared with control treatment ( infested with the causal fungus). Compost was the most efficient in this regard compared with the other three items of disease management. i.e. the bioagents B.subtilis and P.flurescens as well as soil solarization when each of them was used alone, being $11.5,13.3,13.0$ and $12.0 \%$,

Table 4. Effect of combination among the bioagents B.subtilis and P.flurescens, compost and soil solarization on the management of strawberry Fusarium wilt (Camarosa cv.) as well as fruit yield and it's T.S.S., plot experiment.

\begin{tabular}{llll}
\hline Treatments & \% Wilt severity & Weight of fruits (kg)/ plot & Total soluble solids \\
\hline Compost (C) & 11.5 & 5.6 & 16.2 \\
B.subtilis (BS) & 13.3 & 4.4 & 16.0 \\
P.flurecens (PF) & 13.0 & 4.7 & 15.9 \\
Solarization (S) & 12.8 & 5.0 & 16.0 \\
C +BS & 9.0 & 6.2 & 16.4 \\
C + PF & 8.5 & 6.8 & 16.5 \\
C+S & 8.2 & 7.0 & 16.6 \\
BS + PF & 10.0 & 6.1 & 16.1 \\
BS + S & 10.0 & 6.1 & 16.1 \\
PF+S & 10.0 & 6.1 & 16.1 \\
C+ BS+PF+S & 0.0 & 9.0 \\
Control (Infested soil) & 46.8 & 2.3 \\
Control (Uninfested soil) & 0.0 & 9.0 \\
L.S.D. at 5 \% & 2.1 & 2.9 \\
\hline
\end{tabular}

respectively. No apparent infection was detected when the combination among the bioagents B.subtilis and P.flurescens, compost and soil solarization was used and the produced fruit yield and it's T.S.S. ,to somewhat, similar to control treatment (uninfested with the causal fungus). The highest disease severity and poor fruit yield as well as T.S.S. were noticed for strawberry plants grown in soil infested with the causal fungus .

\section{Discussion}

Nowadays, farmers are interested in reducing dependence on chemical inputs, so rather than chemical control such as agriculture practices, sanitation, biological control, resistant cvs. , soil solarization ...ect could be exploded to play an important role in Integrated Pest Management (IPM) systems, especially in case of vegetable production. A model describing the several steps required for a successful IPM has been developed by Mc Spadden and Fravel (2002) .

Akram et al.(2013) mentioned that $F$. oxysporum is a soilborne in nature and invades vascular system of a plant internally. It is better to protect the entrance point of this fungus in plant instead of changing the entire soil mycoflora. For this purpose, some microorganisms can be used to induce resistance in plants for combating with this devastating pathogen.

Isolation trials from strawberry plants showing mainly wilt symptoms grown at Behera, Ismailia, Kalubia and Giza governorates yielded Fusarium oxysporum , F.solani, Macrophomina phaseolina,Pythium ultimum, Phytophthora cactorum , Rhizoctonia solani and Sclerotium rolfsii. the isolated fungi were previously isolated by Abada (1986); Mass (1998) and Fang et al. (2011) and (2012). Pathogenicity test of the four isolates of F.oxysporum revealed that they caused wilt symptoms and Kalubia isolate was the most virulent one. In addition, inoculating different seven plants, i.e. cucumber, eggplant, bean , pepper, strawberry, tomato and water melon with $F$. oxysporum isolate of Kalubia governorate indicated that it caused wilt symptoms to strawberry only. Therefore, it named Fusarium oxysporum f.sp. fragariae Winks \& Y.N. Williams.

Culture filtrate of four Bacillus spp. and one isolate of Pseudomonas flurescens resulted in different degrees of inhibitory effect on the linear growth of F.o f.sp. fragariae, 5 
days after incubation at $30 \pm 2^{\circ} \mathrm{C}$ compared with control treatment. In this respect, the fungus failed to grow on the concentration of $100 \%$ culture filtrate of B.subtilis and $P$. flurescens. However, $P$. flurescens was the most efficient in reducing the linear growth of the causal fungus followed by the isolate of $B$. subtilis . Meanwhile, $B$. coagulans was the lowest effective one in reducing the linear growth of the causal pathogen then the isolate of $B$. pumilus .

Ramamoorthy et al.(2001) mentioned that the treatment with biopreparation induce systemic resistance as the main mechanism of activity on a plant or might be due to $P$. fluorescens produce different types of antibiotics including active 2, 4 diacetyl- phloroglucinole (2,4 DAPB), which control diseases and/or due to that $P$. fluorescens has several methods to control the disease such as production of antifungal compounds including siderophre production, nutrient competition and the induction of systemic resistance. Moreover, Meena et al. (2006) mentioned that the reduction in the infection by the plant pathogens and the increase in the plant length and fresh weight of the treated plants might be due to that $P$. fluorescens produces of indole acetic acid as a growth regulator as well as some antibiotic, i.e. pyrrolnitrin, pyoluterin and 2, 4 diacetyl phloroglucino.

Protection of plants from disease by induction of systemic resistance is a new approach. This is much less harmful to the environment as compared to deadly agrochemicals applied to control plant diseases (Kloeppe et al.,2004).

Jacobsen et al. (2004) mentioned that Bacillus-based biological control agents (BCAs) have great potential in integrated pest management (IPM) systems; however, relatively little work has been published on integration with other IPM management tools. Unfortunately, most research has focused on BCAs as alternatives to synthetic chemical fungicides or bactericides and not as part of an integrated management system.

Sterilized aqueous filtrate of the tested compost resulted in significant reduction to the linear growth of the tested fungus compared with control treatment. This reduction was gradually increased by increasing it's concentration.

Using of the two bioagents B.subtilis and P.flurescens, compost and soil solarization resulted in significant reduction to the severity of strawberry Fusarium wilt with significant increase to the fruit yield and it's total soluble solids (T.S.S.) compared with control treatment. In addition, the combination between any of the tested bioagents and soil solarization was more efficient in reducing disease severity and increasing fruit yield and it's T.S.S. than when each of them was used alone. Moreover, the combination among the two bioagents + compost + soil solarization was the most efficient in this regard, which no apparent infection by the disease was detected and the highest fruit yield and it's T.S.S. were obtained. The highest efficiency of the combination between soil solarization and any of compost and B.subtiis or P.flurescens may be greatly due to the drastic effect of soil solarization on the fungus prop gules make them to be week to resist the invasion by the tested bioagents and compost plays a suitable medium for reproduction and establishment of the added bioagents and saprophytic microbes in the soil .

IPM is a sustainable approach to managing pests by combining biological, cultural, physical and chemical tools in a way that minimizes economic, health and environmental risks. Therefore, this work evaluates the integrated use of genera Bacillus and Pseudomonas as BCAs with another disease management including compost and soil solarization. This integration is important because the consistency and degree of disease control by genera Bacillus and Pseudomonas as BCAs is rarely equal to the control afforded by the best fungicides or bactericides. In theory, integration of several tools brings stability to disease management programs. Integration of genera Bacillus and Pseudomonas as BCAs with other disease management tools often provides broader crop adaptation and both more efficacious and consistent levels of disease control. In this respect, Noble and Coventry (2005) reported that composts have also been shown to suppress several diseases in the field, although the effects have been generally smaller and more variable than in container experiments. The disease suppressive effect of compost generally increased with rate of application. Compost inclusion rates of at least $20 \%(\mathrm{v} / \mathrm{v})$ are normally required to consistently obtain a disease suppressive effect, particularly in peat-based media, but significant disease suppression has been found at lower inclusion rates in soil.

Kwok (1987) declared that copiotrophic bacteria recolonize composts most rapidly (24-48 h) after peak heating of compost. He added that the predominant biocontrol agents in this group include strains of Bacillus, Pseudomonas and Pantoea species. In addition, Lookwood (1988) reported that edaphic microorganisms stimulated by compost amendments contribute to the suppressive activity of the amended soil through four control mechanisms ,i.e. antibiosis, competition, predation hyperparasitism and the induction of systemic acquired resistance in the host plant.

It is supposed that Bacillus spp. could be have diverse plant response involved in synthesis and accumulation of antimicrobial phytoalexins (Hammond-Kosack and Jones, 1996), induction of hypersensitive response ( He et al.,1993), production of defense-related proteins $(\mathrm{Yu}, 1995)$ production of activated oxygen species (Baker et al.,1993), and modification of plant cell wall by deposition of callose (Veit et al.,2001).

Nonpathogenic bacteria, such as various species of the genus Bacillus (Kloepper et al., 2004) can induce a distinct broad-spectrum resistance response in both below- and above-ground parts of the plant. This type of resistance to diseases is named as induced systemic resistance (ISR) (Van Loon,2007 and De Vleesschauwer et al.,2009). Recently, there has been a growing interest in nonpathogenic bacteria due to their efficacy as bioagents in many crops (Kloepper et al., 2004; Akram et al., 2013 ; Zaher et al., 2013 and Abada and Ahmed, 2014). Application of some Bacillus strains to the seedlings has been found effective for suppressing soil borne diseases and has successfully induced systemic resistance in the treated plants (Kloepper et al., 2004 and Szczech and Shoda, 2007). 
It is presumed that the induced chitinase, $\beta$-1,3-glucanase and peroxidase in localized and split-root experiments may be involved in the reduction of vascular wilt development in tomato. Reduced disease severity coupled with enhanced enzyme production elicited by $\mathrm{S}_{2} \mathrm{BC}-1+\mathrm{GIBC}-\mathrm{Jamog}$ in localized and split-root experiments indicate that its mode of action or vascular wilt suppression in tomato is through both direct biocontrol and ISR (Shanmugam and Kanoujia, 2011) Also, Yu et al. (2011) reported that B. subtilis CAS15 has great potential for plant growth promotion and biological control, where reduced the incidence of Fusarium wilt in pepper significantly by $12.5-56.9 \%$ due to induced systemic resistance. They added that there were significant increases in plant height also enhanced the yield of pepper by shortening the time to 50 percent flowering to 17.26 days, increasing the average fruit weight $36.92 \%$, and increasing the average yield per plant $49.68 \%$. This research showed that B. subtilis CAS15 has great potential for plant growth promotion and biological control.

It is well known that soil solarization is a special mulching process which causes hydrothermal disinfestation and other physical and biological changes in soil which are beneficial to plant health and growth. Plastic film laid over moist soil during periods of high air temperature, usually for 1-2 months, can greatly reduce or eradicate a number of pathogens and pests including fungi, bacteria, nematodes, arthropods and weeds. In this regard, Kodama and Fuki (1982) found out that the propagules of F.o.f.sp.fragariae were not detected at $5 \mathrm{~cm}$. soil depth of the solarized soil and population at 10-15 depth showed a $60 \%$ decrease. They added that as a results disease incidence was significantly reduced in outdoor cultivation of strawberry and in closed plastic houses population density of the pathogen filled sharply and remained low for 9 months following soil solarization . Also, Stapleton et al.(1985) reported that soil solarization is a special mulching process which causes hydrothermal disinfestation and other physical and biological changes in soil which are beneficial to plant health and growth. Plastic film laid over moist soil during periods of high air temperature, usually for 1-2 months, can greatly reduce or eradicate a number of pathogens and pests including fungi, bacteria, nematodes, arthropods and weeds. They added that following soil solarization, growth of microflora beneficial to plant growth or antagonistic to pathogens and pests may slow the reinfestation of soil by these organisms for more than one growing season. Increased plant growth and yield of annual and perennial field, row, and nursery crops usually occur following soil solarization. In addition, the availability of increased mineral nutrients following solarization may reduce crop fertilization requirements. Soil solarization has been effective as a preplant and as a post-plant treatment, and has been compatible with chemical soil treatments and also biological soil amendments after solarization. They added that soil solarization is a significant advance in the non-chemical control of many pathogens and pests.

It has been mentioned that phytopathologists have begun to characterize the determinants and pathways of induced resistance stimulated by bioagents and other non-pathogenic microbes (Park, 1995 and Bargabus, et al.,2004) . The first of these pathways, termed systemic acquired resistance (SAR), is mediated by salicylic acid (SA), a compound which is frequently produced following pathogen infection and typically leads to the expression of pathogenesis-related (PR) proteins. These PR proteins include a variety of enzymes some of which may act directly to lyze invading cells, reinforce cell wall boundaries to resist infections, or induce localized cell death. A second phenotype, first referred to as induced systemic resistance (ISR), is mediated by jasmonic acid (JA) and/or ethylene, which are produced following applications of some nonpathogenic rhizobacteria. Interestingly, the SA- and JA- dependent defense pathways can be mutually antagonistic, and some bacterial pathogens take advantage of this to overcome the SAR.

\section{References}

[1] Abada, K. A. ( 1986 ) . Pathological studies on root-rot of strawberry. Ph. D. Thesis, Fac. of Agric., Cairo Univ.,Egypt.

[2] Abada K. A. and Ahmed M. A. (2014).Management Fusarium wilt of sweet pepper by Bacillus strains. The American J. of Life Sci., 2(3): 19-25.

[3] Akram ,W.; Mahboob A. and Javel A.A.(2013). Bacillus thuringiensis strain 199 can induce systemic resistance in tomato against Fusarium wilt . Europ. J. of Mirobiol. and Immunol., 275-280.

[4] Attia, M.F.; Khalil F.A. and Abada K.A. (1989). Pathological studies on strawberry wilt disease . 3 ed Nat Cong. of Pests and Dis. of Veg. and Fruits in Egypt and Arab Count., Ismailia, 304-314.

[5] Baker K. F. (1987). Evolving concepts of biological control of plant pathogens. Annu. Rev. Phytopathol.,, 25:67-85.

[6] Bargabus R. L.; Zidack N. K.; Sherwood J. W. and Jacobsen B. J. (2004). Screening for the identification of potential biological control agents that induce systemic acquired resistance in sugar beet. Biological Control, 30:342-350.

[7] Booth C. (1971). The genus Fusarium. Kew, UK: Commonwealth. Mycological Institute.

[8] Dennis C. and Webster J. (1971). Antagonistic properties of species groups of Trichoderma. III. Hyphal interaction. Trans. Brit. Mycol. Soc.,57: 363-369.

[9] De Vleesschauwer D. and Hofte M.. (2009). Rhizobacteriainduced systemic resistance. Adv. Bot.Res.; 51:223-281.

[10] Domsch K.H.; Gams W. and Anderson T.H. (1980). Compendium of Soil Fungi. Vol. 1 and 2, Academic Press. London.

[11] Fisher, R. A. (1948).Statistical Methods 6th ed. Iowa State Univ. Press, Ames, Iowa, USA.

[12] Hammond-Kosack K.E. and Jones J. D. (1996). Resistance gene-dependent plant defense responses. Plant Cell, 8 (10): 1773-1791. 
[13] He S.Y.; Huang H.C. and Collmer A.(1993 ). Pseudomonas syringae pv. syringae Harpin Pss: a protein that is secreted via the Hrp pathway and elicits the hypersensitive response in plants. Cell.,73(7):1255-1266.

[14] Hervas A.; Landa B. and Jimenez-Diaz R. ( 1997). Influence of chickpea genotype and Bacillus sp. on protection from Fusarium wilt by seed treatment with nonpathogenic Fusarium oxysporum. European Journal of Plant Pathology, 103: $631-642$.

[15] Holt J.G. and Krieg N.R.(1984). Bergey's Manual of Systematic Bacteriology. Williams \& Wilkins, Baltimore,USA.

[16] Fang,Z.; Phlippis D.; Li H. ; Sivasithamparam K. and Barbetti M.J. (2011).Comparisons of virulence of pathogens associated with crown and root diseases of strawberry in Western Australia with special reference to the effect of temperature. Scientia Horticulturae , 131(22):39-48.

[17] Fang,Z.;You M.P and Barbetti M.J.(2012).Reduced severity and impact of Fusarium wilt on strawberry by manipulation of soil $\mathrm{pH}$, soil organic amendments and crop rotation. Europ. J. of Plant Pathol.., 134(3):619-629.

[18] Juber K.S.;Al-Juboory H.H. and Al- Juboory S.B. (2014). Fusarium wilt of strawberry caused by Fusarium oxysporum $\mathrm{f}$. sp. fragariae in Iraq and its control. Journal of Experimental Biology and Agricultural Sciences,2(4):419-427.

[19] Jacobsen B.J.; Zidack N. K. and Larson B. J. (2004).The role of Bacillus-based biological control agents in integrated pest management systems: Plant Diseases. Phytopathology, 94(11):1272-1275.

[20] Kloepper J.W.; Ryu C.M. and Zhang S. (2004). Induced systemic resistance and promotion of plant growth by Bacillus spp. Phytopathology, 94(11):1259-1266.

[21] Kodama T. and Fuki T. (1982). Solar heating in closed plastic house for control of soil borne diseases. V. Application for the control of Fusarium wilt of Strawberry. Ann. Rev. of the Phytopathol. Soc. of Japan, 48:570-577.

[22] Kwok O.C.H ; Faby P.C.; Hotink H.A.J. and Kuter G.A.(1987). Interaction between bacteria and Trichoderma harzianum in suppression of Rhizoctonia damping-off in bark compost media. Phytopathology,77:1206-1212.

[23] Lockwood, J.I.(1988). Evaluation of concepts associated with soil borne plant pathogens. Annu. Rev. Phytoathol., 26:93-121.

[24] Maas J.L. (1998). Compendium of Strawberry Diseases. The American Phytopathological Society, Second edition, pp128.

[25] Mc Spadden G. B., and Fravel, D. (2002 ). Biological control of plant pathogens: Research commercialization, and application in the USA. Online. Plant Health Progress doi:10.1094/PHP-2002-0510-01-RV.

[26] Meena, B.; Marimuthu T. and Velazhahan R. (2006). Role of fluoroscent pseudomonas in plant growth promotion and biological control of late leaf spot of groundnut. Acta Phythopathologica et Entomologica Hungarica, 41(3-4): 203212.

[27] Noble R. and Coventry E. (2003).Suppression of soil-borne plant diseases with composts: A review. Biocontrol Science and Technology, 15(1):3-20.

[28] Oedjijono, M. A. L. and Dragar, C. (1993). Isolation of bacteria antagonistic to a range of plant pathogenic fungi. Soil Biol. Biochem., 25: 247-250.

[29] Park, S. K.; Lee, H. Y. and Kim, S. C. (1995). Antagonistic effect of chitinolytic bacteria on soil borne plant pathogens. Kor. J. Plant Pathol., 11: 47-52.

[30] Parry, J.M.; Turnbull P.C.B. and Gibson J.R. (1983). A colour atlas of Bacillus species, Wolfe Medical Publications Ltd.

[31] Ramamoorthy, V.; Viswanathan R.; Raguchander T.; Pkakasam V.and Samivappan R. (2001). Induction of systemic resistance by plant growth promoting rhizobacteria in crop plants against pests and diseases .Crop Protect., 20(1): 1-11.

[32] Santoyo G.; Orozco-Mosqueda M.D.C. and Govindappa M. (2012).Mechanisms of biocontrol and plant growth-promoting activity in soil bacterial species of Bacillus and Pseudomonas: a review. Biocontrol Science and Technology, 22: 855-872.

[33] Shanmugam V. and Kanoujia N. (2011). Biological management of vascular wilt of tomato caused by Fusarium oxysporum f.sp. lycospersici by plant growth-promoting rhizobacterial mixture. Biological Control, 57 ( 2 ): 85-93.

[34] Snedecor, G.W. and W.G. Cochran, 1967. Statistical Methods. 6th Ed. Iowa State Univ. Press, Ames, Iowa, USA.

[35] Stapleton J.J.; Quich J. and Devay J.E. (1985). Soil solarization: Effects on soil properties, crop fertilization and plant growth. Soil Biol. and Biochem., 17(3):369-373.

[36] Szczech M. and Shoda M. (2006).The effect of mode of application of Bacillus subtilis RB14-C on its efficacy as a biocontrol agent against Rhizoctonia solani. J. Phytopathol., 154:370-377.

[37] Ulloa M..; Hutmacher R . B.; Davis R . M..; Wright S. D.; Percy R., and Marsh B. (2006).Breeding for Fusarium wilt race 4 resistance in cotton under field and greenhouse conditions. The J. of Cotton Sci., 10:114-127.

[38] Van Loon L.C. (2007).Plant responses to plant growth promoting rhizobacteria. Eur. J. Plant Pathol., 119:243-254.

[39] Veit S.; Wörle J.M.; Nürnberger T.; Koch W. and Seitz H.U.(2001). A novel protein elicitor (PaNie) from Pythium aphanidermatum induces multiple defense responses in carrot, Arabidopsis, and tobacco. Plant Physiol.,127(3):832-841.

[40] Yu L.M.(1995). Elicitins from Phytophthora and basic resistance in tobacco. Proc. Natl. Acad. Sci. U S A., 92(10):4088-4094.

[41] Yu X.; Ai C. ; Xin L. and Zhou G.(2011).The siderophore producing bacterium, Bacillus subtilis CAS15, has a biocontrol effect on Fusarium wilt and promotes the growth of pepper. Eur. J. Soil Biol.,47(2):138-145.

[42] Zaher, Effat A.; Abada, K.A. and Zyton, Marwa A. (2013). Effect of combination between bioagents and solarization on management of crown-and stem-rot of Egyptian clover. J. of Plant Sci., 1 ( 3):43 -50 . 